Vol. 5, No. 1, 2020

\title{
ENVIRONMENTAL SAFETY MANAGEMENT OF USED PACKAGING OF PESTICIDES AND OTHER DANGEROUS SUBSTANCES
}

\author{
Roman Petruk $^{1}$, Ihor Petrushka ${ }^{2}$, Volodymyr Pohrebennyk ${ }^{2}$ \\ ${ }^{1}$ Vinnytsia National Technical University, \\ 95, Khmelnytsky Hwy., Vinnytsia ,21021, Ukraine \\ ${ }^{2}$ Lviv Polytechnic National University, \\ 12, S. Bandery Str., Lviv, 79013, Ukraine \\ prroma07@gmail.com
}

https://doi.org/10.23939/ep2020.01.030

Received: 21.01 .2020

(C) Petruk R, Petrushka I., Pohrebennyk V., 2020

\begin{abstract}
In Ukraine, there is a problem of environmentally hazardous handling of used packaging of pesticides and other toxic chemicals and hazardous waste which can pose a serious threat to human health and the environment. The paper presents modern methods of disposal of pesticide packaging in the world and the situation in Ukraine. The Ukrainian and world environmental legislations regulating the problem of pesticide packaging management are analyzed. The scheme of processing and disposal of pesticide containers is proposed. Types and materials from which pesticide packaging is made are analyzed. Methods and equipment for washing of pesticide containers and handling of washing solutions are given. As a result, it is recommended to intensify the process of organizing a system for collecting, certifying and setting up licensed pesticide and other hazardous waste disposal facilities, as well as ensuring state support and the use of the best international experience.
\end{abstract}

Key words: ecological safety, pesticides, hazardous waste, pesticide packaging, recycling.

\section{Introduction}

Pesticides are extremely poisonous, so packaging must ensure that these products do not leak into the environment even during long-term storage. Equally important is the continued disposal of used empty containers sometimes with minor pesticide residues, which can pose a direct threat to the environment and human health and other living ecosystems. In Ukraine, unfortunately, the problem of collection and disposal of empty containers, in particular from pesticide preparations, is not given sufficient attention and this problem is not solved. Therefore, managing the ecological safety of pesticide packaging requires scientific justification and the development of practical recommendations for the relevant environmental services.

The purpose of this study is to analyze the state of disposal of pesticide packaging and to develop measures for the improvement of the environmental safety of the industry. The tasks are to analyze Ukrainian and world experience in pesticide packaging management, to analyze legislation and to develop ways of handling pesticide packaging and packaging for Ukraine. The object of the study is the process of handling and processing of pesticidal packaging. The subject of the study is packaging methods and packaging for pesticides. Research methods include the literary search, collection, analysis and processing of information.

\section{Experimental part}

Pesticides are stored and transported in appropriate packaging with special marking and warning strips (labels, signs) of the following colors:

- red - herbicides;

- white - defoliants;

- black - insecticides;

- green - fungicides;

- blue - etchants;

- yellow - pheromones, attractants.

At the same time pesticides of high degree of danger are transported in steel drums, barrels, and special containers. Medium toxicity pesticides are transported in containers made of polymer materials, wooden boxes, and low toxicity pesticides - in paper and cardboard bags, etc. This is regulated, in particular, by the Decree of the 
Cabinet of Ministers No. 354 of March 27, 1996, as well as by the Law of Ukraine "On Pesticides and Agrochemicals". Marking and transportation of pesticides are carried out according to the state standard DSTU ISO 7409: 2003 and the sanitary rules of DCPIN 8.8.1.2.00198. Pesticide storage facilities and containers must comply with all the sanitary standards and be provided with appropriate material and technical base. Containers intended for disposal may also be stored on special sites and sheds to which unauthorized persons and animals have no access. These structures should also be dry and carefully insulated against moisture, etc. 1-5].

Pesticide packaging should be disposable. All packaging operations are governed by Decree No. 915 of July 26, 2001 "On Implementation of the System of Collecting, Sorting, Transportation, Processing and Disposal of Waste as Recycled Material", as well as Decree No. 354 of March 27, 1996 "On Approval of the procedure of disposal of unsuitable or prohibited pesticides and agrochemicals and their containers" with amendments made in 2008, 2011 and 2012. The legal regulation of packaging operations is described in [6]. However, these materials, for the most part, regulate reusable packaging products, in particular, solid household waste.

The list of licensees on hazardous waste management is widely known in Ukraine, including the Vinnytsia region. These are private enterprise "Yureko", the company "Podilska Sich", the emergency rescue unit of the special purpose of the Main Directorate of the Civil Service for Emergency Situations, and the company "Vinecoresource". Only the latter enterprise is authorized to do operations with packaging for pesticides and hazardous waste. These operations are as follows: collection, storage, treatment, disposal, but not recycling.

Several years ago, more than 1000 tons of pesticides from Dzhurin poison burial ground were refilled into plastic containers and exported outside Ukraine. As a result, several hundred rusty metal barrels of 2001 pesticides that require disposal remain in its territory [7-12]. The pesticides that have been transplanted and taken out are:

- DDT;

- fosamide;

- metaphos;

- hexachlorocyclohexane ( $\gamma$-isomer).

However, more than 2000 tons of pesticides are still stored in the territory of the specified poison burial ground awaiting their overloading, final purification, and completion of exporting of these pesticides to the places of their processing and thermal disposal. At the same time, the decree No. 644 of November 11, 2014, of the Vinnytsia Regional State Administration assigned the functions of property management of the former interregional point of disposal of toxic chemicals (the village of Dzhuryn of Shargorod district) to the Department of Ecology and Natural Resources of the Vinnytsia Regional State Administration.

Figure 1 presents a schematic diagram of pesticide packaging management. Empty packaging, including pesticides and other hazardous waste, is mostly the waste that can be used as raw material for processing or a source of energy, and after special treatment (cleaning), it can be reused. In the case of double cleaning of containers with special surfactants or triple-washing with water, it can be reused, but not for domestic purposes.

However, packaging that has not been completely cleaned is disposed by incineration (plastic, paper, burlap, etc.), and metal containers and barrels may be recycled at the relevant metallurgical enterprises. Unfortunately, in our country, there are almost no points for collecting pesticide packaging. However,two enterprises in Ukraine are licensed to dispose hazardous waste of pesticide packaging. It is the enterprise "National Center for Hazardous Substances Management" and the company "Capital-2006". Besides, there is one landfill in the Kropyvnytskyi region for the disposal of such containers. Soon, it is planned to open some more such landfills for the disposal of packaging in Ukraine. Today, the level of collecting pesticide containers by authorized companies is only about $1 \%$ of the imported ones. It is planned to bring this figure to $30 \%$ soon. Tariff rates per ton of packaging are in the range of 12-15 thousand UAH.

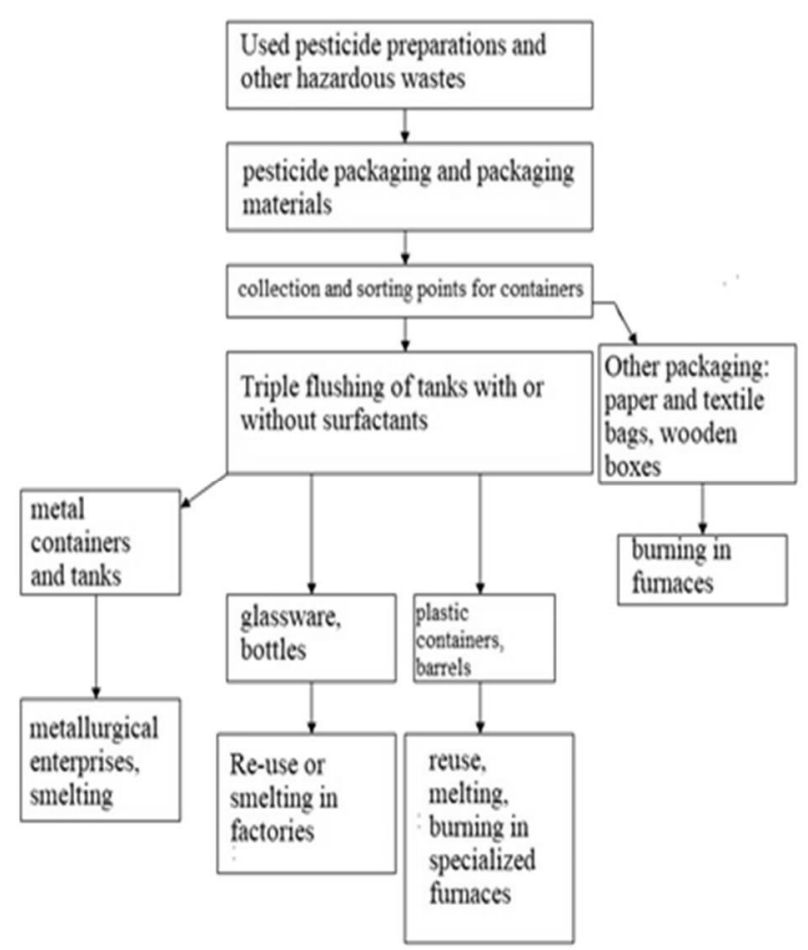

Fig. 1. Scheme of processing of pesticide containers 
The procedure of triple flushing of packaging plastic proves that the residue of pesticides in water-emulsion extracts after rinsing of barrels and containers is from $99 \%$ to $100 \%$. The washing water can be used as a working pesticide solution or for the preparation of new portions of concentrate for cultivation. Thus, the packaging becomes safe and suitable for further processing or use, avoiding incineration.

There are several ways to minimize pesticide waste generation and packaging:

- to reduce the use of pesticides by replacing them with more efficient counterparts and more efficient application;

- to wash the container three times or use the equipment for washing under pressure;

- to use large pesticide containers instead of small ones.

More careful control over pesticide use and packaging management should be exercised. In the EU, pesticide users are required to conclude a contract with a carrier registered at the Environmental Agency and a licensed waste disposal contractor (packaging, incl.). Documentation on the receipt and transfer of pesticides and waste is kept for two years. Solutions and materials used in the flushing and cleaning of sprayers and tanks after the end of the operation enter the waste. In Ukraine, such materials and solutions are not currently collected and are therefore released into the
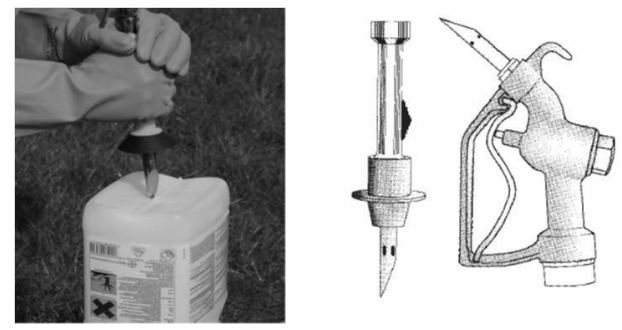

Fig. 2. Pesticide plastic packaging equipment and the process of piercing

Containers that are not suitable for rinsing (such as paper bags and cardboard boxes) are usually emptied completely but not flushed. Such containers should be stored empty and treated as if they still contain pesticides and should be disposed by the licensed waste disposal contractors.

At the same time, having closed the caps on the containers tightly, immediately after washing and drying, they should be stored vertically in a place protected from the atmosphere until disposal.

Methods of handling containers after washing:

- to transfer to a licensed waste disposal contractor;

- to take to a licensed site for the disposal of waste; environment. European legislation allows small residual volumes of unconcentrated washing solutions to be discharged into the soil, but under certain conditions:

- the soil must absorb the volume of liquid to be recovered without draining or puddles;

- lower the risk to wildlife and watercourses;

- protect groundwater (preventing the pesticide from entering water bodies);

- pose the least risk to septic tanks, runoff or sewage systems;

- place enclosures wherever necessary to limit contact between humans and livestock.

Under certain circumstances and approval, the discharge of flushing water into the local sewage system is permitted.

\section{Disposal of packaging}

Pesticide containers may only be used for pesticide filling. Any other ways of use are prohibited. After using, the packaging is washed with a mandatory puncture to prevent the reuse. There are recommendations from $\mathrm{WHO}$ and FAO [13-24] on how to do this properly. The equipment for this purpose has been designed. Restriction on the flushing of tanks exists only for gaseous powders of hydrogen cyanide or aluminum, magnesium or zinc phosphides, due to the possibility of the formation of toxic gases upon contact with water.
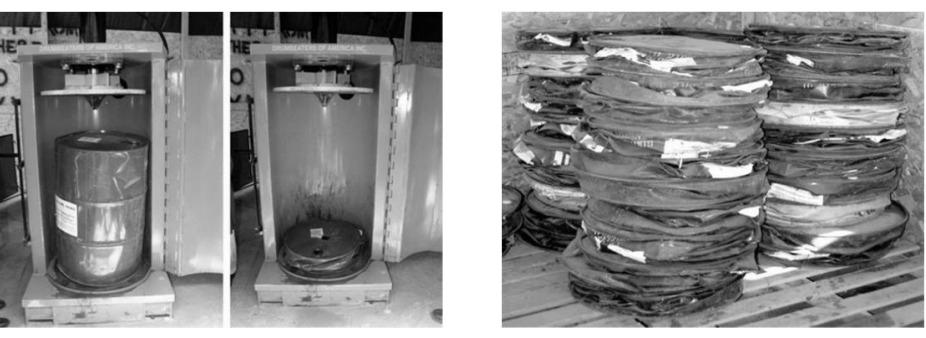

Fig. 3. The process of piercing, washing, and pressing of metal pesticide containers

- to burn on the incineration equipment with the permission of local authorities or the environmental protection body (in some EU countries, only specialized licensed factories are allowed to burn).

Unwashed containers from pesticides are considered to be hazardous waste, and those properly washed conventional municipal solid waste.

Shredded plastic packaging can be used as the raw material for burning at the cement production facilities in a rotary kiln, or as the raw material for the production of certain plastic products, such as low-pressure pipes or sewage pipes.

There is almost no problem of packaging in the EU and the US, as the collection system works quite effectively, and 
the penalties for non-compliance with the legislation in this area are significant. In Ukraine, there is a rather low level of control over packaging for food or household products and,

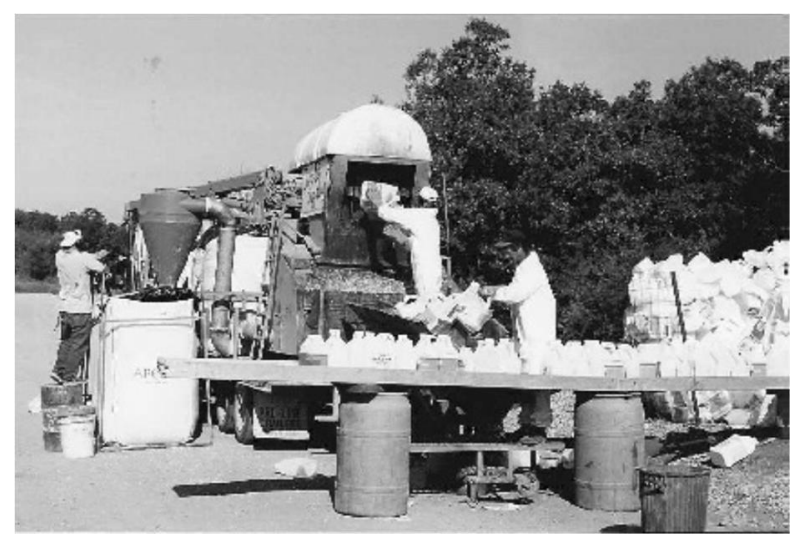

similarly, for packaging for dangerous and toxic substances and pesticides. Therefore, the bulk of such packaging falls into landfills at best.

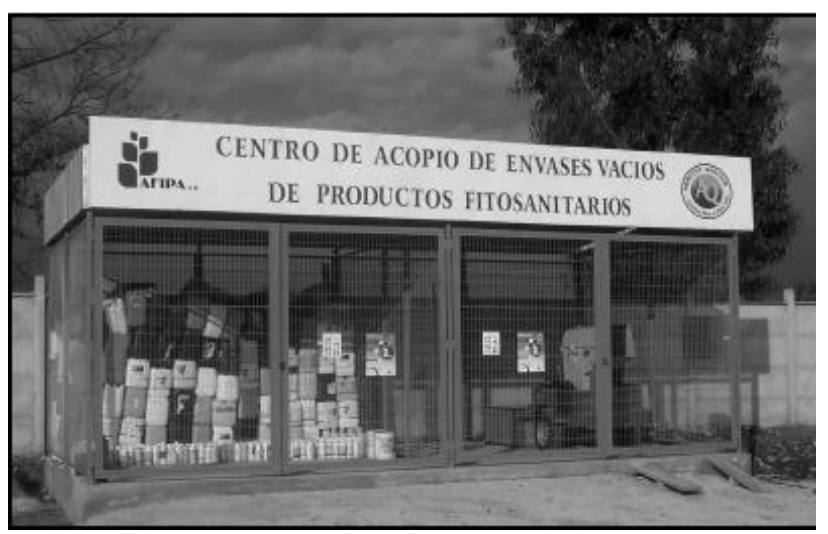

Fig. 4. A pesticide collection center in Chile and a process of shredding washed plastic containers in a mobile shredder

\section{Disposal of other wastes}

In the course of work with pesticides, another waste containing pesticides is formed, for example, contaminated packaging, equipment, treated seeds, personal protective equipment for workers, respirator cartridges, and clothing. Sometimes, such waste should be treated as hazardous.

\section{Types of pesticide containers}

There are several basic types of pesticide containers. A 10-liter and a 20-liter plastic container is common for liquid pesticides. Dry pesticides are often sold in sealed plastic bags. There are also pressurized pesticide (aerosol) containers, which are usually made of metal. There is also a type of container that is reusable and returned to the manufacturer for refilling. There is no need to wash such containers. In Ukraine, they are not widespread, as most pesticides in our country are foreign.

\section{Recycling of containers in Ukraine}

In 2011,11 points for collection of used pesticide containers in five regions of Ukraine were created to implement agreements between the Ministry of Ecology, the National Center for Hazardous Waste Management and the EBA Agronomic Committee. This is the first step towards creating a high-quality system for managing empty packaging for pesticides and mineral fertilizers. However, in the Zhytomyr region (Baranivka, EkoNova LLC), a line for the disposal of pesticides of the I-III hazard class with the potential capacity of 200-300 tons per month has been launched recently.
The company is processing pesticide packaging, providing monthly disposal services of approximately UAH 1.5 million. The company claims that at high temperatures, harmful substances such as oxins and dioxins disappear. However, according to the Basel Convention, the company that created them is responsible for the waste. The processing technology, for example, of plastic canisters, is reduced to washing, grinding, and further these pieces of plastic (especially from lowpressure polyethylene) can be the raw material for sewer pipes and the like. If the waste is incinerated, this process takes place in a furnace with the temperature of $1000{ }^{\circ} \mathrm{C}$. As a result, the elementary combustion compounds $\left(\mathrm{H}_{2} \mathrm{O}\right.$, $\mathrm{CO}_{2}, \mathrm{CO}$, and others) are formed at the outlet, and further burnt in the corresponding chamber at $\mathrm{t}=1100{ }^{\circ} \mathrm{C}$ to avoid the formation of dioxins and active radicals. The container recycling plant also uses scrubbers and filters in the chimneys to comply with hygiene and environmental standards.

Fig. 5 presents comparative indicators of waste recycling in Ukraine and the EU countries, including packaging and hazardous waste of the I-III class.

Thus, in the pesticide packaging management plan, it is necessary to develop measures to tightly control the number of pesticides purchased and used by agribusiness and firms engaged in their sale, as well as to control containers and packaging for hazardous substances. At present, such control is almost inoperative, as a large part of the pesticides sold are smuggled and therefore untreated. This scheme shows that in Ukraine, the process of recycling and processing of hazardous substances, including containers and packaging for them, is only at an initial 
stage. Therefore, to finally solve the problem of effective management of the environmental safety of empty containers from pesticides and other hazardous substances, several organizational and environmental measures should be taken and their state support should be ensured.

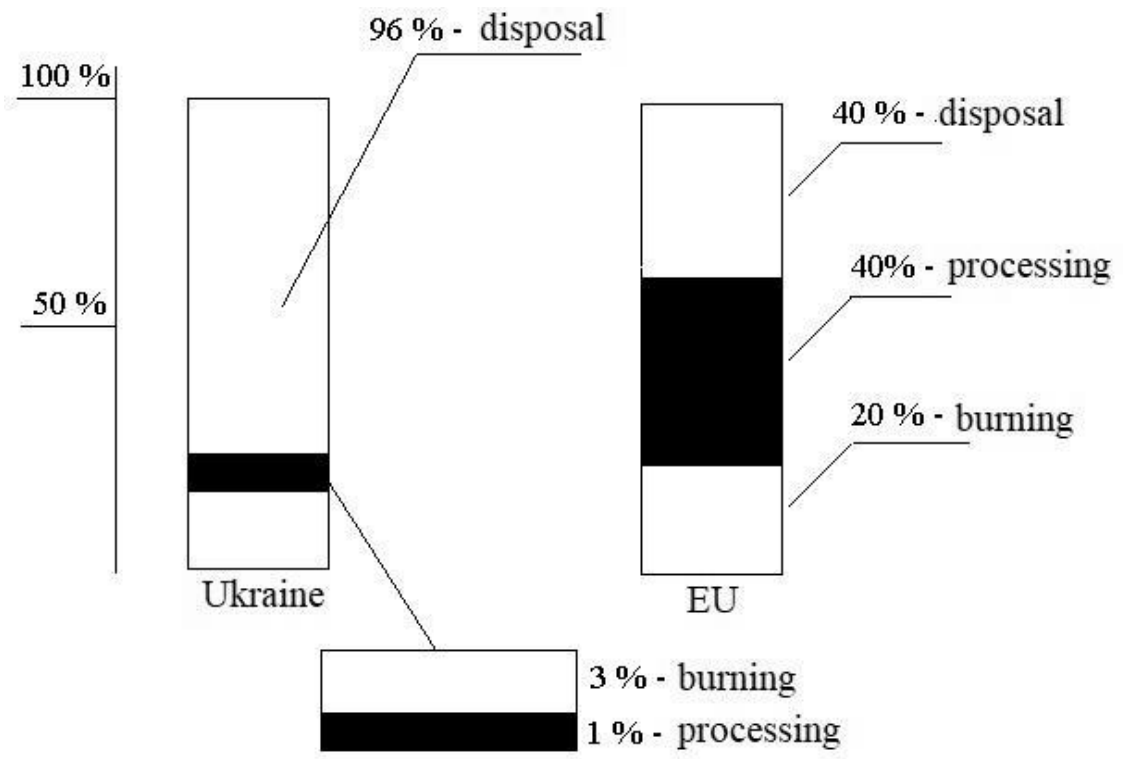

Fig. 5. The state of the container handling in Ukraine and the EU

\section{Conclusions}

The paper deals with the problem of ensuring the effective management of the ecological safety of used containers and packaging for pesticides and other dangerous substances in Ukraine. A comparative characteristic with EU countries is made. As a result, it is recommended to intensify the process of organizing a system for collecting and sorting such waste, as well as create appropriate licensed enterprises for the processing of not only hazardous waste but also its packaging. Besides, it is necessary to comprehensively develop our own and use the world's best technologies for the processing and disposal of packaging, as well as the experience of the leading countries in Europe and the world to effectively solve these problems.

\section{References}

[1] Koval I. I., Pohrebennyk V. D.: J. Envir. Sci. and Natural Resour. 2018, 4 (28), 94.

[2] Hushtan T. A.: J. Logos, 2016, 961.( in Ukrainian)

[3] Podolchak I. I., Pohrebennyk V. D.: Mizhnarod. naukov.sympozium "Stalyy rozvytok - stan ta perspektyvy”, Lviv-Slavske 2018, 134.

[4] Siryk T. A. : J. Upakovka, 2011, 4, 60.

[5] Mykhalkiv A. A.: Normatyvno-pravove rehulyuvannya utylizatsiyi tary, Problemy teoriyi ta metodolohiyi bukhhalterskoho obliku, kontrolyu i analizu, 2012, 2 (23), 189. (in Ukrainian)

[6] https://zakon.rada.gov.ua/laws/show/994_b05
[7] Kozak A.: Upakovka odnorazova chy bahatorazova, Kharchova i pererobna promyslovist, 2000,1,31.

[8] Siryk T. A.: Visn. SumDU, Seriya Ekonomika, 2011,3,49. (in Ukrainian)

[9] Slabkyy V. H.,. Kryvoshey V. M: J. Upakovka, 2011, 6,49. (in Ukrainian)

[10] Artyushenko A. Y., Kostenko O. P.: VNTU "KHPY", 2017,160 .

[11] Marzena Ucherek: Opakowania a ochrona srodowiska, Krakow, Wydawnichtwo Akademii Ekonomicznej w Krakowiw, 2005,70

[12] http://www.fao.org/agriculture/crops/corethemes/ theme/pests/pm/code/en/

[13] http://www.fao.org/fileadmin/user_upload/ obsolete_pesticides/ docs/w1604e.pdf

[14] http://www.unece.org/trans/danger/publi/adr/ adr2007/07ContentsE.html

[15] http://www.unece.org/trans/danger/publi/ghs/ ghs_rev02/02files_e.html

[16] http://www.ag.ndsu.edu/pubs/plantsci/pests/ ae1052w.htm

[17] http://edis.ifas.ufl.edu/PI010

[18] http://www.basel.int/

[19] http://www.ecpa.eu/dashboard/life-cycle/containermanagement-and-disposal-obsolatestock

[20] EU. European Waste Catalogue, European Commission Decision 2001/118/EC (asamended by 2001/119/EC), 2001

[21] http://www.unep.org/stap/

[22] http://www.ilo.org/ilolex/cgi-lex/convde.pl?C170

[23] http://chm.pops.int/default.aspx

[24] http://www.pic.int 